\title{
Correction to: Preclinical Development of Cell-Based Products: a European Regulatory Science Perspective
}

James W. McBlane' • Parvinder Phul ${ }^{\prime} \cdot$ Michaela Sharpe $^{2}$

Published online: 20 September 2018

(C) The Author(s) 2018

\section{Correction to: Pharm Res}

https://doi.org//0.1007/sI 1095-018-2437-y

The article Preclinical Development of Cell-Based Products: a European Regulatory Science Perspective, written by James W. McBlane, Parvinder Phul, and Michaela Sharpe, was originally published electronically on the publisher's internet portal (currently SpringerLink) on 25 June 2018 without open access.

With the author(s)' decision to opt for Open Choice the copyright of the article changed on 6 September 2018 to (C) The Author(s) 2018 and the article is forthwith distributed under the terms of the Creative Commons Attribution 4.0 International License (http://creativecommons.org/licenses/by/4.0/), which permits use, duplication, adaptation, distribution and reproduction in any medium or format, as long as you give appropriate credit to the original author(s) and the source, provide a link to the Creative Commons license and indicate if changes were made. The original article has been corrected.

Open Access This article is distributed under the terms of the Creative Commons Attribution-NonCommercial 4.0 International License (http://creativecommons.org/licenses/ by-nc/4.0/), which permits any noncommercial use, distribution, and reproduction in any medium, provided you give appropriate credit to the original author(s) and the source, provide a link to the Creative Commons license, and indicate

The online version of the original article can be found at https://doi.org/l 0 . | 007/s | | 095-0 | 8-2437-y

James W. McBlane

james.mcblane@mhra.gov.uk

Licensing Division, Medicines \& Healthcare Products Regulatory Agency,

10 South Colonnade, Canary Wharf, London EI 4 4PU, UK

2 Nonclinical Safety, Cell and Gene Therapy Catapult, Guy's Hospital, I2th Floor, Tower Wing B, London SEI 9RT, UK 